REVISTA DE GESTÃO ESECRETARIADO

MANAGEMENT AND ADMINISTRATIVE

PROFESSIONAL REVIEW

ISSN: 2178-9010
Revista GeSec

São Paulo, SP, Brasil

v. 12 , n. 3, p. 111-135

set./dez. 2021

DOI: http://dx.doi.org/10.7769/gesec.v12i2.1241

\title{
Secretarial work in pandemic times: new skills or old tasks?
}

\section{O trabalho secretarial em tempos de pandemia: novas habilidades ou velhas tarefas?}

Tabata Rhomanel Bette ${ }^{1}$

Débora Carneiro Zuin ${ }^{2}$

Odemir Vieira Baêta ${ }^{3}$

Nathalia Carvalho Moreira ${ }^{4}$

\begin{abstract}
This paper aimed at raising the perception of secretaries about interferences or redimensions in the usage of their skills, due to the remote work modality, imposed by the Covid-19 pandemic. A qualitative research was carried out through semi-structured interviews with eight executive secretaries working in the private sector. Among the main results obtained, it was found that most of the interviewees noticed changes in the usage of their skills, due to the varied changes in their work scopes, as well as the new environment, providing them more autonomy and freedom. In the post-pandemic context, most respondents confirmed that the companies they work for, will not return to work in the same way and perspective as it was before.
\end{abstract}

Keywords: Secretarial work. Skills. Remote Work. COVID-19.

\section{Resumo}

Este artigo objetivou analisar a percepção dos secretários sobre interferências ou redimensionamentos no uso de suas competências, devido à modalidade de trabalho remoto, imposta pela pandemia Covid-19. Foi realizada pesquisa qualitativa tendo como técnica de coleta de dados entrevistas semiestruturadas com oito secretários executivos do setor privado. Dentre os principais resultados, constatou-se que a maioria dos entrevistados observou mudanças no uso de suas habilidades, devido às mudanças em seus contextos de trabalho, bem como no novo ambiente, proporcionando-lhes mais autonomia e liberdade na realização de tarefas. No contexto póspandêmico, a maioria das respondentes considerou que as empresas para as quais trabalham, provavelmente não voltarão a trabalhar da mesma forma e perspectiva de antes.

Palavras-chave: Secretariado. Técnicas Secretariais. Trabalho remoto. COVID-19.

\footnotetext{
${ }^{1}$ Bacharel em Secretariado Executivo Trilíngue.

${ }^{2} \mathrm{PhD}$ in Organizational Studies, Docente na Universidade Federal de Viçosa (UFV).

${ }^{3}$ Doutor em Administração, Docente na UFV.

${ }^{4}$ Doutora em Administração Pública, Docente na Universidade Federal de Juiz de Fora (UFJF).
} 


\section{Introduction}

The first case of infection by the new coronavirus (Severe Acute Respiratory Syndrome Coronavirus 2 - Sars-Cov-2) was reported to the World Health Organization (WHO) in China, in the city of Wuhan, on December 31, 2019 (Lana et al., 2020). The quick escalation of the disease (Covid-19) that spreaded globally led WHO to classify it as a pandemic on March 11, 2020. Its high transmission capacity has made the world seek to adapt quickly and in many ways, with social isolation being one of the most effective means indicated by health authorities (WHO, 2020).

In Brazil, the Ministry of Health declared the recognition of community transmission of Coronavirus throughout the national territory on March 20. The recommendation, according to law No. 13,979 / 2020, was that society should adopt measures to promote social isolation and avoid crowding. In this sense, millions of male and female workers had their work activities impacted, adjusting to a new type of work: the remote, in the home office regime (Bernardo et al, 2020). Oliveira and Tosta (2020) state that the disease has altered health structures, economic and social activities around the world, changing people's lives and the routines of organizations in the most diverse aspects.

In a study by Barbosa et al. (2020), 60.8\% of the participants said that in the post pandemic scenario, companies will adopt this way of working (remote) due to the countless advantages it presents. As a result, it is relevant to understand the perception of the working executive secretarial professionals, regarding the skills used by them in the current home office regime, in this pandemic period of Covid-19. Such information is predominant for future professionals in this area, since in order to fit into the current job market, they must not only adapt to this format but also check the possibility of developing new professional skills that are in accordance to it.

In this context, this research has as main aim to raise the perceptions of the executive secretarial professionals about possible interferences or resizing in the usage of their professional skills, due to the Covid-19 pandemic.

This study starts from the following question and sets the motivation for researching the topic as proposed: in view of the scenario caused by the Covid-19 pandemic, concerning the condition of work in the home office format, what are the possible changes perceived by the executive secretaries currently working, in relation to the usage of their secretarial skills?

In order to obtain an answer to this question, the following aims were defined: The main objective was to raise the perception of executive secretarial professionals about the skills used in remote work. In addition, the study also had the specific aims, as following: a) Analyze 
whether the executive secretarial professionals working during the pandemic perceived any new requirements, in terms of secretarial skills, for this new type of work; b) analyze whether the skills addressed by them are different from the profile presented by the authors used in the theoretical framework of this article; c) to raise the perceptions of the executive secretaries working during the pandemic on the secretarial skills needed for the professional future of this area, in the post-pandemic context.

For the methodology, the exploratory and descriptive research was used, the approach being predominantly qualitative. As a data collection instrument, semi-structured interviews with eight executive secretarial professionals from the private sector were used, made by videoconference, due to the context of social isolation. For data analysis, the content analysis method of Bardin (2006) was used in order to raise the main categories for analysis.

The results of this study shows that the scope of work of executive secretary professionals may change and their perception is that is already changing. Because respondents believe that companies see remote work as the new standard modality that will continue after the pandemic.

With that in mind, this work is divided into five sections, with this introduction followed with the theoretical framework. In the latter, the context of Covid-19 and its consequent implications as to the world of work is presented. Then, the professional skills concerning the profile of the executive secretary, and, finally, it has sought to make explicit the skills consistent with the remote modality in secretarial work.

In section 3, the methodological procedures adopted were explained, followed by the presentation and data analysis in section 4. Subsequently, the conclusion and references of this research.

\section{Theoretical Framework}

\subsection{Covid-19 and changes in work}

On January 5th, 2020, the World Health Organization (WHO) received a statement from the Chinese Government about a series of cases of pneumonia of unknown origin in Wuhan, a Chinese city with a population of 11 million people (Lana et al, 2020). On January 9th, the virus was identified and its genetic code released as belonging to a family of viruses that causes respiratory infections. Since then, the virus has spread quickly in several countries around the world. The speed and intensity of population contamination led the World Health Organization (WHO, 2020) to classify the disease as a pandemic on March 11, 2020. It is also noteworthy 
that the difficulty of testing suspects and isolating them further expanded the number of cases (Silva, 2020).

In Brazil, since the registration of the first case, confirmed on February 26th, the virus has also spread quickly and permeated all Brazilian states. Given the lack of a vaccine against the disease and given the intensity of the morbidity and mortality rates observed in several countries, the most appropriate strategy to contain the spread of the virus, pointed out by the World Health Organization - WHO - and by authorities and specialists from the health sphere, was social isolation. Thus, the Ministry of Health of Brazil regulated the recommendations of the isolation and quarantine criteria to be applied by the local authorities of each state to patients with suspected or confirmed coronavirus infection in the country, through the publication of an ordinance in the Federal Official Gazette on March 12th.

On March 20th, the Ministry of Health declared the recognition of community transmission of coronavirus throughout the national territory and the recommendation was that all national managers should take measures to promote social distance and avoid crowding. In addition, it was recommended to reduce commuting to work, with the encouragement of virtual meetings; postponing or canceling non-essential trips; carrying out work at home (home office) and, finally, the adoption of alternative schedules, to avoid peak periods. For educational institutions, the planning of vacation anticipation was recommended, with the possibility of using remote education.

Faced with the new disease, the world went through a period of rehabilitation due to the pandemic. Companies in the most diverse fields had to adjust to teleworking in order to continue meeting deadlines and work activities. In addition to the devastating health-related consequences of the population, the Covid-19 pandemic has had strong implications for the way people live and work, affecting their physical and mental well-being (Ahrendt et al, 2020). In a short period of time, the invisible enemy has transformed homes into full-time jobs and schools, adapting the lives of those who live there (Oliveira \& Tosta, 2020).

In this direction, people and organizations have changed their ways of acting and living, seeking to contain the rapid spread of the disease. In the meantime, the concept called "new normal" emerged, when people need to adapt their lives, human and labor relations in order to maintain their jobs and "coexistence" among human beings.

The United Nations - UN (2020) has claimed that millions of people around the world are working remotely due to the Covid-19 pandemic, and now experts are questioning whether this could be the future of work for those people, whose job does not require physical presence in a specific location. In a home office regime, a real revolution in the job market is common. According to Oliveira \& Tosta (2020), in view of the beginning of the New Coronavirus 
pandemic, several companies saw in the law the possibility of keeping themselves working through remote work. Thus, many employees from Brazil and the world continued to provide services in their own homes.

Predictions that teleworking would become a dominant mode of work date from the 1980s and the beginning of the information revolution (Toffler, 1980). According to Bouquet (2020), although the technology to facilitate remote work has existed for more than a decade, Covid-19 forced hundreds of millions of employers and employees around the world to engage in a sudden, massive and in real time remote work experience, with new work arrangements.

According to the International Labor Organization (ILO, 2020), before the pandemic, there were already many discussions about the implications of using technology for the future of work. However, this future was anticipated and forced, drastically changing the way we work. Remote virtual meetings are now commonplace and economic activity has increased across multiple digital platforms. Some large companies in developed economies have already said, according to the United Nations - UN (2020), that what has been an unplanned pilot remote work - will become the standard way of organizing work. Many employees will not need to travel again, unless they choose to do so. The International Labor Organization - ILO estimates that, in high-income countries, $27 \%$ of workers will work from home.

In a study made by Oliveira \& Tosta (2020), which aimed to understand working conditions during the pandemic, the increase in workers' autonomy was identified, but also the expansion of working hours, due to the needs of several meetings, which sometimes exceed the normal stipulated hours. In addition, it was found by several respondents that productivity was increased, because they had to work harder to supply the desired, while others said that their productivity was reduced, because they were sharing the space of the house with other people, who also perform their working tasks.

Coeckelbergh (2020) states that confinement changed a good part of the habits, customs and ways of being of individuals. From the moment the population was forced to live in forced isolation, behavioral patterns changed, triggering serious impacts on personal and, especially, professional relationships. According to Ravi Gama, CEO of the 2FIND company and associate member from LIDE FUTURO, the hiring criteria will inevitably undergo changes, mainly related to the behavioral area. Therefore, he points out that companies will look for candidates that have greater flexibility, creativity, self-management, self-discipline, motivation and proactivity, since the concerns will focus more on the way these people work, that they can produce without the presence of their bosses. In addition, with the future heading towards a moment of innovation, circumstances will require a prepared professional, to deal with an extremely digital and technological world. 
In a study by Barbosa et al. (2020), $60.8 \%$ of the participants believe that in the post pandemic scenario, companies will adopt remote work, giving more importance to selfmanagement and autonomy. The data showed that more than half of those surveyed believe that the majority of workers are able to adapt to new means of work, remote and virtual means, to continue the worker's functions in the home office mode.

According to a report by Maia and Müller (2020), in the secretarial area, remote work is not something new, however it was used by a small portion of professionals, and now, a large portion of these professionals are working remotely. In this study, which aimed to survey working conditions in the secretarial area, in the remote mode, $67 \%$ of the respondents claimed that there were changes in relation to the pace and speed of work: increased volume of activities, but also more time to dedicate to them, without interruptions from supervisors or colleagues. In addition, $50 \%$ of respondents believe that their work can be developed completely remotely, which implies that companies may start to prefer this type of format.

Therefore, it is noted that there have been numerous changes in the world of work due to the condition provided by the Covid-19 pandemic, not only in terms of activities, but also in terms of market demands for new skills.

\subsection{Secretarial skills}

In Brazil, to define skill, it is necessary to define competence. The definition of competence is widely accepted in both academic and organizational environments (Dalmau \& Leal, 2020), and comes from the study of authors such as Dutra (2002; 2004); Fleury (2001; 2002; 2004) and Brandão (2005; 2007), with an integrative approach to the theme, supported by the fundamental pillars of Durante (2000): knowledge (understanding); knowing how to do (skills) and knowing how to be (attitudes), focusing on both the contextual issue and the performance presented. According to Durante (2000), knowledge refers to the knowledge accumulated throughout life, which makes it possible to understand the world from interpretations; know what and why to do something. This refers to the ability to act according to predefined objectives; usage of knowledge productively, albeit empirically. Attitude, finally, means wanting to do, having a predisposition, desire or intention to accomplish something.

According to Santos and Ferreira (2014), the traditional profile of the secretary changed and started to occupy a strategic position within companies, where he is concerned with understanding and having an opinion on important matters, being able to direct the client to viable solutions. and mediate deadlocks so as not to overburden executives. With technological advances, many jobs are eliminated, and the new functions require more skills, knowledge and competences, (...) "the secretarial professional, in the current context, in the result of a specific 
and wide academic training, can take advantage adapting to the increasingly demanding labor market" (Santos \& Ferreira, 2014, p. 74).

According to Cegan et al. (2015, p. 138), the current job market is extremely competitive for all professional areas, which demands from the secretarial professionals both practical skills of their profession as well as social and communication skills, which are some of the elements that make up the set of demands of the contemporary labor market for professionals from the most varied areas. According to Almeida et al. (2018), the skills needed by the secretarial professional cover not only the technical sphere, but also the behavioral one. As a result of their studies, five sets of behavioral skills were found to be the most important in the contemporary market: relationship with the client, teamwork, time management, negotiation and creativity/innovation.

Given that companies hire professionals for technical skills, but often fire due to lack of behavioral skills, emotional intelligence has become a skill required by the modern world in organizations. According to Cordeiro and Rosa (2015, p.137) "with technological advances and the increasingly demanding job market, it is essential that professionals remain emotionally, socially and technically prepared". According to Fontes (2018, p. 41), emotional intelligence is a competence composed of skills such as: creating and maintaining healthy relationships, having leadership skills, motivating people, working as a team and creating credibility with clients, therefore being essential skills for any professional, especially for the executive secretarial professionals. According to Fontes (2013, p. 45), emotional intelligence skills allow this professional to exercise his competencies successfully, increase the quality of work and his productivity: "a complete professional is one who gathers technical, intellectual and also emotional skills". This way, you will be able to make important decisions, coordinate teams and deal with people of different personalities. According to the author, the emotionally intelligent executive secretary is one who uses emotions in order to improve his professional skills.

With regard to technological skills, with the increasing global integration of companies, there was a multiplication of the offer of products and services, fostering the trend towards internationalization, demanding changes in the forms of competition and intensifying the usage of digital technologies and increasing constant technological and managerial innovations. In this context, Martins et al. (2015) affirm that the executive secretary who aims to stand out in organizations should seek to meet the demands of the market, with knowledge about Information and Communication Technologies being paramount.

In the case of advisory skills, according to Giorni (2017), the act of understanding and supporting, using their specific knowledge as a basis, is required from the professional to provide assistance in the existing problem. Thus, the advisory is configured as an attitude of 
holistic vision, in view of the organizational reality, in which the secretary adapts to the needs of organizations for the exercise in an adjunct role to decision-making centers.

For Aguilar and Souza (2017), organizations are currently looking for proactive professionals; dynamic; competent; with boldness, maturity and emotional control to take calculated risks; who have a global view of the organization's business and are able to foresee problems and present solutions; and that, with strategic knowledge, are able to add value to the function they perform, contributing to the success of the organization as a whole. Other competences are also attributed to the professional profile of the contemporary executive secretary, as illustrated in Chart 1:

\begin{tabular}{|c|l|}
\hline \multicolumn{2}{|c|}{ Contemporary Skills of the Secretarial Professional } \\
\hline \multirow{5}{*}{ Technical } & $\begin{array}{l}\text { Strategic thought; organization; planning; assistance and advisory; entrepreneurship; information } \\
\text { collection; innovate and elaborate objectives in the organization; time management; cooperativism; } \\
\text { information management; protocol knowledge; event organization; foreign languages; secretarial } \\
\text { techniques; registration and distribution of files; mastery of office skills and technologies; solution } \\
\text { programmer; orientation of evaluation and selection of correspondence; knowledge of procedures, } \\
\text { rules and resolutions; conflict mediation; writing specialized professional texts; usage of available } \\
\text { communication and information resources and softwares; logical reasoning; file and process } \\
\text { management; ability in diverse areas such as administration, economics, accounting, finance, } \\
\text { marketing, financial mathematics, legislation, human resources, mastery of the Portuguese language } \\
\text { and ability to identify opportunities for growth. }\end{array}$ \\
\hline Behavioral & $\begin{array}{l}\text { Leadership, initiative; motivation; Communication capacity; ability to adapt to changes; professional } \\
\text { ethics; responsibility; dynamism; self control; flexibility; creativity; discretion; negotiation skills; } \\
\text { commitment; empathy; good interpersonal relationship; emotional balance; proactivity; common } \\
\text { sense; professionalism; team work; conflict management; versatility, perceptiveness; efficiency and } \\
\text { efficacy; knowledge of the company and sight of the entire company; dedication; punctuality; } \\
\text { attendance; sensitivity; decision-making; delegation and acting as a facilitating agent. }\end{array}$ \\
\hline
\end{tabular}

Chart 1. Contemporary skills of Secretarial Professionals

Source: Moreira et al. (2016, page. 53).

Therefore, it is possible to observe, in chart 1, the range of skills in the technical and behavioral spheres needed by the secretarial professional, which demonstrates how holistic their profile needs to be. According to Werner and Oliveira (2014), over time the secretarial profession has evolved along with the labor market and following technological development, so that today many secretarial activities are mediated by Information and Communication Technologies (ICT) tools. According to research by Cegan et al. (2015), both technical and higher level professionals, it was found that mastery and knowledge of archival and computer techniques (information systems, internet and Office package) are basic and fundamental requirements for the exercise of the profession. This reflects the change in the profile and performance of secretarial professionals, since the tools of Information and Communication Technologies (ICT) are present in almost all daily activities within the secretarial area.

Revista Gestão e Secretariado (GeSec), São Paulo, SP, v. 12, n. 3, set./dez., 2021, p. 111-135. 
According to Andrade et al. (2015), being the executive secretary responsible for document management in organizations and acting as a facilitating agent in the flow of communication, the result of his work provides support to managers, especially information. Thus, the manipulation of information through the tools of Information and Communication Technology becomes essential for the executive secretary to efficiently assist the information management process.

Furthermore, Cegan et al. (2015) also state that higher level professionals work in the strategic areas of organizations, performing tasks and activities that require a more reflective attitude and hold broad knowledge about the company where they work. Therefore, skills such as team supervision, telephone and customer service, control/organization/conducting meetings and events, and for that, good communication that reduces the risks of noise in information, are demanded in the profession at the same time.

With regard to behavioral skills, Cegan et al. (2015) verified that professionals with organizational skills are requested, in addition to dynamism and proactivity. In addition, there is a need for emotional intelligence, given that skills and abilities to work under psychological pressure are required.

According to Fontes (2018), emotional skills allow the executive secretary to exercise his competencies successfully, increasing the quality of work and his productivity. Therefore, such tools are essential for this professional, besides contributing, also, to deal with unforeseen situations and under pressure, generating competitive advantages for the company.

The same author also states that emotional intelligence is in the self-control and balance of emotions, in the face of conflicts that may arise in work relationships, not allowing personal problems to negatively affect the performance of their tasks. In addition, it is of great value for the executive secretary to be able to understand how people work and what motivates them, making them work in their favor, in order to improve their work routine.

In a research made by Ribeiro et al. (2020), it was observed that proactivity was cited as essential for maintaining its employability by $50 \%$ of respondents. The second most cited term was updating, present in the speech of $30 \%$ of academics, justifying that "keeping up to date is important, that is, through professional courses, as in the technological area. Responses such as posture, self-management, responsibility, ethics, leadership and commitment were also addressed.

\subsection{Remote Modality in Secretarial Work}

For purposes of definition, in the Consolidation of Brazilian Labor Laws (CLT), article 
83 , it is defined that the home worker is the one who provides services at home, having an employer who pays him (Brazil, Consolidation of Brazilian Labor Laws. Text of Decree - Law number 5,452 , article 83 , p. 20). Also according to the CLT, the definition of remote work - or telework - is the work that is performed by the employee in a place other than where the company is established, whether it be in their homes or not. Even if the place of execution of the task is different, the law defines that there can be no difference between virtual work and work performed in the company, as mentioned in article 6 (Brazil, Consolidation of Brazilian Labor Laws. Text of Decree - Law number 5.452, article 6, p. 2). Therefore, the difference between remote work and home office is that the first one can be performed in any environment outside the office (library, cafeteria, park or at home); the home office, on the other hand, is a mode of remote work, and must be carried out specifically in the worker's home environment.

Regarding the remote work of the executive secretarial professional, Quoos et al. (2015) argue that the scope of work of the secretarial professional remains the same, both in person and virtually, as this position allows him to continue providing his services with quality and efficiency, regardless of his location. For the authors, updates to the agenda, writing, typing, delegation of tasks, dispatch with the manager, travel arrangements and meetings can be carried out remotely without any impact on the agility and quality of these activities.

The success of this type of work depends on the adaptability of this professional to change from traditional to flexible work (Abreu et al, 2018). For Raghuram et al. (2001), an author who explored factors that directly influence the success of remote work, divided them into two categories/dimensions: structural, which deals with the physical structure and displacement of the professional, and relational, which deals with the psychological part of the professional. Charts 2 and 3 show how these factors are distributed:

\begin{tabular}{|c|l|}
\hline Work independance & $\begin{array}{l}\text { Work independence: Technological advancement allows employees to work } \\
\text { independently outside the office. Interacting with his colleagues, accessing the } \\
\text { company's online tools, being able to do his work with quality (THOMPSON, 1967) }\end{array}$ \\
\hline $\begin{array}{c}\text { Clarity of evaluation } \\
\text { criteria }\end{array}$ & $\begin{array}{l}\text { Important to guarantee equal rights between traditional and flexible employees } \\
\text { (KURLAND; EGAN, 1999). In addition, evaluation criteria are essential to generate } \\
\text { feedback and guide and reinforce employee performance in flexible working } \\
\text { positions }\end{array}$ \\
\hline
\end{tabular}

Chart 2. Structural Factors.

Source: Abreu et al. (2018 page 30). 


\begin{tabular}{|c|l|}
\hline & $\begin{array}{l}\text { It is generated by the relationship of trust established between virtual workers and } \\
\text { their organizational partners (RAGHURAM et al., 2001). According to Ferreira } \\
\text { (1988), trust is the intimate security of the procedure, in this case, the work partner, } \\
\text { and it comes, according to Bachmann and Zaheer (2006), from the decision to trust } \\
\text { one another under a risky condition, even because a good interpersonal relationship, } \\
\text { among the components of a team, increases the effectiveness in coordinating tasks, } \\
\text { including distance (LIN; STANDING; LIU, 2008). }\end{array}$ \\
\hline $\begin{array}{c}\text { Organizational } \\
\text { connectivity }\end{array}$ & $\begin{array}{l}\text { It concerns the feeling of belonging of the virtual professionals in relation to their } \\
\text { teams and the organization, even though they are physically distant. This feeling } \\
\text { interferes with the desire of such professionals to continue with a long-term } \\
\text { relationship with their partners (BAUMEISTER; LEARY, 1995; RAGHURAM et } \\
\text { al., 2001). }\end{array}$ \\
\hline
\end{tabular}

Chart 3. Relational Factors

Fonte: Abreu et al. (2018 pág. 30)

That way, it is perceived that technical and infrastructure factors are relevant for a good adaptation to remote work, but also behavioral, which are related to feelings and how the worker perceives himself acting in the modality and in the organization.

\section{Methodology}

The approach adopted was predominantly qualitative, since it sought to understand the phenomenon - the skills used in the remote performance of the executive secretarial professional in the Covid-19 pandemic. According to Lakatos and Marconi (2010), this approach allows us to analyze more specifically the habits, attitudes and behavioral trends of a given population.

With regard to the objectives, this research is classified as descriptive, since it describes the perception that executive secretarial professionals have in the context that permeates the study, agreeing with the post by Gil (2002), when he defines that such type of research focuses on describing the characteristics of a particular population or phenomenon. As for the researcher's nature, it is a basic research, since the intention is to concentrate knowledge and information to support important academic or applied results (Schwartzman, 1979). Thus, what is intended is to contribute with information about the secretary who has acted remotely in the pandemic scenario of Covid-19.

In this case, scientific papers were used that deal with the basic theory of this study, that is, work in the Covid-19 era and the skills of the executive secretarial professional. Therefore, it can be considered that the data collection technique was bibliographic research, which, according to Gil (2002), uses already prepared materials as a base, mainly books and scientific articles. Laws and materials from organizations such as UN, ILO and WHO were also used in this study, which can be characterized as documentary, which differs from the bibliographic in 
the nature of the sources, as it is material without analytical treatment (Gil, 2002).

Complementing the data collection is the field survey, carried out through the application of semi-structured interviews, which allows at the same time the freedom of expression of the interviewed and the maintenance of the focus by the interviewer (Gil, 2010). The questions were elaborated from the theoretical deepening on questions proposed in this project. The manner in which the interview was conducted took place virtually to the detriment of the situation in which Brazil finds itself.

For data analysis, the Content Analysis method was used, which in this research was based on the conceptualization proposed by Bardin (2006), as well as the technical steps explained by this author. Bardin (2006, p.38) says that content analysis consists of: A set of communication analysis techniques which uses systematic and objective procedures to describe the content of the collected information. The intention of the content analysis is the inference of knowledge related to the conditions of production [...]

Thus, semi-structured interviews were carried out with eight executive secretarial professionals, in videoconference, through the Google Meet platform. The universe of the study was made up of professionals who had their work modification changed due to the Covid-19 pandemic, leaving the on-site model for the home office regime. The sample consisted entirely of professionals from the private sector working in Brazilian territory, residents of the southeast and midwest regions, the majority of whom are female and only one male interviewee, all between 25 and 35 years old. The operating segments of the companies that the interviewees work with are: financial, steel sector, law, automobile and strategic and administrative consultancy. The interviews were carried out between 10/26/2020 and 11/9/2020, lasting an average of 30 minutes each.

The interviews were recorded, transcribed, and then the content analysis strategy was used (Bardin, 2006). The registration unit was the basis for the elaboration of the categories, being, according to Bardin (2006), the smallest cut of a semantic order that is removed from the text, which can be a word, a theme, objects, people, among other options. After this identification, the categories, subcategories and themes of analysis were extracted from this content according to the attendance in which they were mentioned. It is noteworthy that the categories were elaborated after data collection, however, duly supported by the theoretical framework studied, validating their importance. Then, the data were analyzed quantitatively, based on the simple frequency of responses.

In order to describe in detail the methodology so that it can be replicated in other situations, we can say that there was an attempt to get a larger number of interviews, however, at the time of this research it was not possible to add more respondents. 
Furthermore, this study used a random and voluntary sample, the age group is explained by the fact that it is a simple random sample. A random sample - which means chance, chance - is good, as it gives all members of a population the same chance of being selected. So, this number really means that we follow the qualitative research rigor, that no one should be favored over another person in the sample selection process.

Probabilistic sampling techniques are techniques for selecting the elements of a population, in order to obtain a representative sample of the population. They should be used to ensure that inferences about the population are valid. Therefore, at the time of the research, the results showed us the age group from 25 to 35 years old and it is emphasized that at another time we can find different results.

In sequence, the interviews lasted approximately 30 minutes because it was enough time for the answers to be fully satisfied and all doubts were resolved, with no need for more time. The choice of the interview themes was based on the categories, subcategories and analysis themes of the words designated in the content analysis, as we can see in chart 4, so they answered great topics on technical skills and behavioral competencies.

Thus, the categories emerged after elaboration and application of the interviews, according to Chart 4 :

\begin{tabular}{|c|c|c|}
\hline Category & Subcategories & Analysis Themes \\
\hline \multirow{8}{*}{$\begin{array}{l}\text { Technical } \\
\text { abilities }\end{array}$} & \multirow{3}{*}{$\begin{array}{l}\text { Mastery of Written } \\
\text { Communication }\end{array}$} & Cohesion and Consistency \\
\hline & & Grammar \\
\hline & & Communication noise \\
\hline & \multirow{2}{*}{$\begin{array}{l}\text { Information } \\
\text { Technology }\end{array}$} & Video Conferencing Platforms \\
\hline & & Information management software \\
\hline & \multirow{3}{*}{ Strategic Knowledge } & Knowledge about the business \\
\hline & & Systematic and analytical view \\
\hline & & Autonomy \\
\hline \multirow{5}{*}{$\begin{array}{l}\text { Behavioral } \\
\text { Skills }\end{array}$} & \multirow{3}{*}{ Self-Management } & Routine \\
\hline & & Time Management \\
\hline & & Self-knowledgment \\
\hline & \multirow{2}{*}{ Adaptability } & Abrupt Changes \\
\hline & & Resilience \\
\hline
\end{tabular}




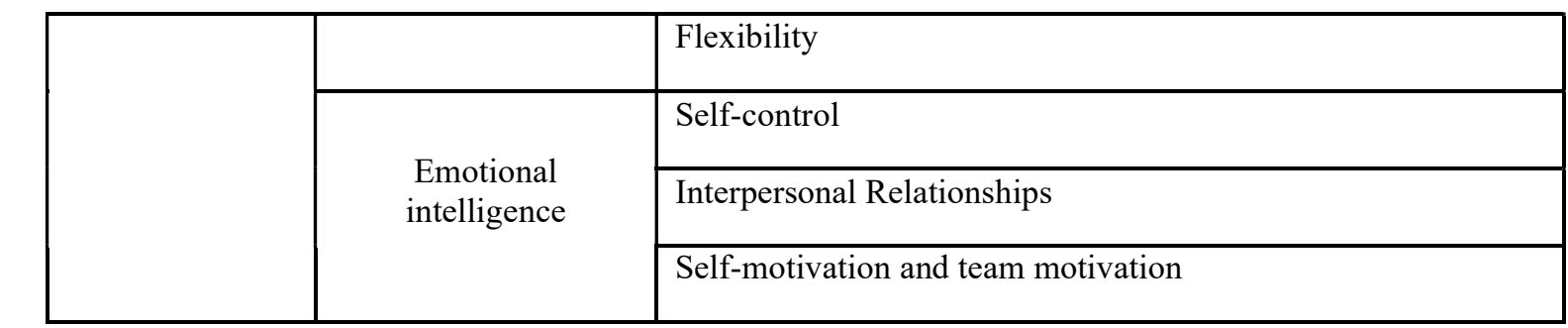

Chart 4. Categories, subcategories and analysis themes

Source: Research Data (2020).

\section{Results and Discussion}

According to what was exposed in the methodology, a research instrument was applied - semi-structured interviews - with the intention of knowing the perception of the Executive Secretarial professionals who had their work modality transformed to home office, seeking to understand if this change impacted the skills used by them. Eight executive secretarial professionals were interviewed, who, in this study, are identified as subjects of the research, and numbered cardinally from 1 to 8 , represented by the nomenclature of E1, E2... E8. Regarding the area of expertise, all respondents are graduates of the Executive Secretarial Course (bachelor degree).

\subsection{The scope of work in the home office regime}

The subjects were asked if they had experienced working remotely before the Covid-19 pandemic began. Of eight respondents, only one had already worked in a hybrid way, alternating remote and in person. In addition, it was asked whether the scope of work, that is, the activities carried out on a daily basis underwent changes with the new type of work. Thus, it was found that six interviewees had their activities partially changed, due to the loss of some and the gain of others. Interviewee E3 had no change in activities and demands, as he was already used to doing his job remotely. Interviewee E6, on the other hand, had her entire scope of work transformed, needing to migrate from area, due to scarcity of demand in the advisory sector:

My demand at least quadrupled. Many people had their hours reduced, and I was responsible for ensuring the amount of work of these people. I gained more text proofreading activities, since we had press releases every day, in addition to having to communicate the same thing several times, like remembering the team about a meeting in several places: phone or video call, whatsapp, e-mail. (E1).

I had a very radical change in my work. The demands started to stop appearing, as I no longer needed to organize trips, events and take phone calls. An application (app) was implemented that the executives themselves scheduled their meetings and the app did everything, so I stopped managing the agenda. Finally, I was responsible for physical maintenance and office supplies, and we are no longer going to the office. I basically lost all my activities, so I was transferred to another area, being a support member in 
the financial resources maintenance sector. (E6)

I didn't suffer so much, because my managers always traveled a lot, it was difficult to have them in person, so a lot of my work was already remote. But my activities are much more executing and strategic than advisory. (E3)

The above goes against the position of Quoos et al. (2015), who says that the scope of work of the secretarial professional remains the same at a distance, since most of the sample had its activities modified. However, it is noteworthy that the scarcity of activities such as organizing events and trips were made impossible due to preventive measures of social isolation.

\subsection{Technical Skills}

Chart 5 shows the category Technical Skills, its subcategories are Mastery of Written Communication, Information Technology and Strategic Knowledge, followed by the Analyzed Themes.

\begin{tabular}{|c|c|c|c|c|c|c|c|c|c|c|c|c|}
\hline & & & & & & & & \multicolumn{4}{|c|}{ Respondents } & \\
\hline Category & Subcategory & Analyzed Themes & 1 & 2 & 3 & 4 & 5 & 6 & 7 & 8 & $\mathrm{~T}^{1}$ & $\mathrm{FT}^{2}$ \\
\hline \multirow{7}{*}{$\begin{array}{l}\text { Technical } \\
\text { Abilities }\end{array}$} & \multirow{3}{*}{$\begin{array}{c}\text { Mastery of } \\
\text { Written } \\
\text { Communication }\end{array}$} & $\begin{array}{l}\text { Cohesion and } \\
\text { Consistency }\end{array}$ & $\bar{X}$ & $\mathrm{X}$ & $\mathrm{X}$ & & $\bar{X}$ & & $\mathrm{X}$ & $\mathrm{X}$ & 6 & 75 \\
\hline & & Grammar & $\mathrm{X}$ & & & & & & $\mathrm{X}$ & & 2 & 25 \\
\hline & & Communication Noise & $\mathrm{X}$ & $\mathrm{X}$ & $\mathrm{X}$ & $\mathrm{X}$ & $\mathrm{X}$ & $\mathrm{X}$ & $\mathrm{X}$ & $\mathrm{X}$ & 8 & 100 \\
\hline & \multirow{2}{*}{$\begin{array}{l}\text { Information } \\
\text { Technology }\end{array}$} & $\begin{array}{l}\text { Video Conferencing } \\
\text { Platforms }\end{array}$ & $\mathrm{X}$ & $\mathrm{X}$ & $\mathrm{X}$ & $\mathrm{X}$ & $\bar{X}$ & $\mathrm{X}$ & $\mathrm{X}$ & $\mathrm{X}$ & 8 & 100 \\
\hline & & $\begin{array}{l}\text { Information } \\
\text { management } \\
\text { softwares }\end{array}$ & $\mathrm{X}$ & $\mathrm{X}$ & & & $\mathrm{X}$ & & $\mathrm{X}$ & $\mathrm{X}$ & 5 & 62.5 \\
\hline & \multirow{2}{*}{$\begin{array}{c}\text { Strategic } \\
\text { Knowledge }\end{array}$} & $\begin{array}{l}\text { Knowledge about the } \\
\text { business }\end{array}$ & $\mathrm{X}$ & & $\mathrm{X}$ & $\mathrm{X}$ & $\mathrm{X}$ & & & $\mathrm{X}$ & 5 & 62.5 \\
\hline & & $\begin{array}{l}\text { Systemic and holistic } \\
\text { view }\end{array}$ & $\mathrm{X}$ & $\mathrm{X}$ & & $\mathrm{X}$ & & & $\mathrm{X}$ & & 4 & 50 \\
\hline
\end{tabular}

\section{Chart 5. Technical Skills}

${ }^{1} \mathrm{~T}=$ Total observations $;{ }^{2} \mathrm{FT}=$ total frequency.

Source: Research Data (2020).

Respondents were asked how they perceived the usage of technical secretarial skills in the home office regime. Interpreting chart 5 , by common agreement, everyone informed about 
their skills with information and communication technologies (ICTs), since their entire workday is being intermediated by digital devices. It is clear that, in this case, having skills with video conferencing platforms was the most evident. In addition, the need to have writing skills in a potentiated way was mentioned, since the flow of information, in view of the context is mostly through texts and messages in whatsapp groups, e-mails and information management platforms, such as Trello, Outlook, and Google Suite:

\footnotetext{
Before, I didn't deal much with information technology, because the company I work for was very traditional and conservative in the way I work. We were not used to doing anything virtual, so I also had no platform mastery, digital signature, digital authentication, anything. I had to seek to train myself. (E1)

I needed to greatly improve my writing communication to try as much as possible to reduce the noise in communication. At those times, a comma in the wrong place, a poorly worded sentence could turn information and demands into a completely different thing compared to what was said. (E7)
}

The above confirms the positions of Werner and Oliveira (2015) and Martins et al. (2015), who state that the secretarial profession has evolved along with the labor market and following technological development, making many secretarial activities mediated by Information and Communication Technologies (ICT) tools. What can be observed in this context is that, in reality, all activities started to be mediated by digital tools, due to social distancing, making technological skills even more demanded. In addition, the mastery of the Portuguese language and grammar is presented in the skills framework of Moreira et al., confirming it as a demand of the secretarial professional profile. Rescuing the speech of Andrade et al. (2015), the executive secretary acts as a facilitating agent in the communication flow, and the result of his work provides support to managers, especially information. What is perceived in the positioning of the interviewees is that communication and the flow of information are mostly written, with the need to master the grammar to build cohesive and coherent texts, in order to minimize communicational noise.

On the same question, five of the interviewees mentioned, as shown in chart 5, the need to have a comprehensive knowledge about the functioning of the business in which they work. Giorni (2017) states that the consultancy is configured as an attitude of holistic view, in view of the organizational reality in which the secretary adapts to the needs of the organizations, for the exercise in an adjunct action to the decision centers. His speech, therefore, is corroborated by more than half of the interviewees, who confirmed that the holistic view of the business was essential for a better adaptation in a context of distance work:

I now see our field as more executive and less assistant, because with the pandemic, everyone, regardless of hierarchy, had to develop secretarial skills (taking care of their own agenda, organizing a call, dealing more directly with the client). Our differential is to have a vast knowledge of the business in which we work at and apply the varied "know-how" we acquired in college, this systematic and holistic view, to solve complex problems in an assertive and quick way. (E3) 
In the pandemic context I understood that knowing the business I was part of, knowing the products, the processes and how things happen was essential to facilitate my work. I think that our profile is no longer personalized for the person we are advising, but personalized to the common goal of the company. (E6)

\subsection{Behavioral Skills}

Chart 6 shows the Behavioral Skills category, its subcategories are Self-Management, Adaptability and Emotional Intelligence, followed by the Analyzed Theme.

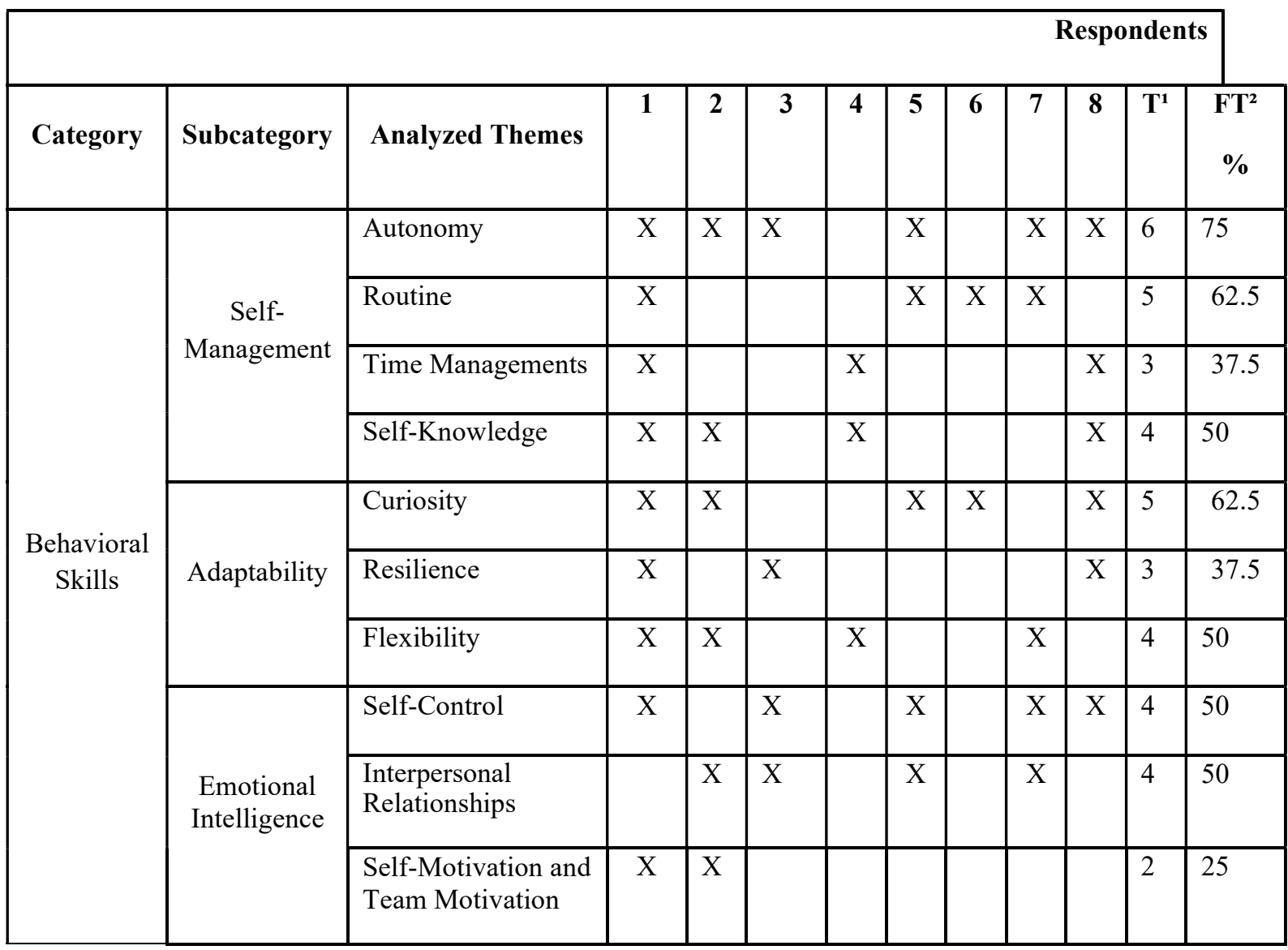

\section{Chart 6. Behavioral Skills}

${ }^{1} \mathrm{~T}=$ Total observations $;{ }^{2} \mathrm{FT}=$ total frequency

Source: Research Data (2020).

It was asked what the interviewees' perception was regarding the usage of behavioral skills demanded by the home office. Analyzing chart 6, it is noted that Self-Management was cited by all respondents, due to the freedom and flexibility that the home office promotes, with no direct supervision:

Another issue is self-management, but looking at the balance part of the workday. At first, I lost that sense of time. I started at 7 A.M. and missed lunch. At night, there were hours without taking breaks. So that was a great challenge, to be able to impose limits. (E1)

In the home office regime I gained more autonomy and flexibility, and this gives you more quality of life, but it makes you need more self-discipline, because you need to put limits on yourself. (E3) 
As an executive secretary we already need self-management, because there is no way to organize an executive's agenda without knowing how to plan my own time. But the point is that now there are no spatial limits, my resting place, domestic chores and work are in the same place. I needed to understand what worked best for me, to know myself in this modality, so that I wouldn't lose productivity. (E5)

Resuming the theoretical framework, Thompson (1967) stated that remote work would actually promote more autonomy for employees, and Moreira et al. (2016) pointed to the importance of self-control and self-discipline in the secretarial routine. However, analyzing the interviewee's speech E5, the lack of spatial limit for the different daily activities in the home office led her to the need to improve not only self-discipline, but also self-knowledge, since there is no such thing as "clock in "or supervisors to limit how the hours of the day are divided:

Before, it was not necessary to understand how your own productivity worked. How you can divide your tasks according to your productivity peaks, and what works best for your reality. The company rules outlined this, and you are the one who should fit in. Now there is autonomy and freedom for you to do this, but it also requires you to know yourself, to make the best choices. (E7)

In the Adaptability subcategory, it can be seen in Chart 6 that curiosity was mentioned by most respondents. Interviewee E8 stated that having the will and openness to learn new tools and ways of working and relating was essential for her adaptation to the new routine:

Without this intense search for wanting to discover and understand new tools and ways of working, my desire to work would greatly decrease, because a lot has changed at the same time. If I were a traditionalist and conservative person, without openness to the new, I would have difficulty adapting. (E8)

I think that more than excellence, which is such a word quoted in our field, I would say that curiosity was extremely necessary in this context. This is also part of being proactive, because when you are curious, you are not satisfied with just what you are presented with, but you yourself are looking for other ways to do and resolve things. (E3)

Moreira et al. (2016) ensure the need for the executive secretarial professional to have flexibility and the ability to adapt to changes. However, they do not address curiosity, as well as other authors of the theoretical framework did not mention it.

In the subcategory Emotional Intelligence, emotional self-control was mentioned by 5 interviewees, shown in chart 6, interpersonal relationships, as well as the team's self-motivation and motivation skills. Rescuing the speech of Fontes (2018, p. 41), emotional intelligence is composed of skills such as: creating and maintaining healthy relationships, having leadership skills, motivating people, working as a team, which are essential skills for any professional, especially executive secretaries. Interviewee E4 stated that, in the context of isolation, many employees had their emotional health affected, including her, since the relationships were transformed. So, in order not to lose productivity, she needed to understand how to deal and react to each emotion and find ways to motivate herself and motivate the team, always seeking to understand her purpose and the purpose of each of her team. 


\subsection{The perception about the future of secretarial work and skills demanded}

Finally, respondents were asked about their perceptions about the future of secretarial work and their skills. In view of the exposed, all respondents confirmed that the companies they work for will not return to work in the same way as before, even after the end of the pandemic, as they realized many benefits, in the remote mode, such as improving the quality of life of employees and reducing costs. This corroborates with the UN research data (2020), stating that the remote modality would become the standard way of organizing work from then on.

Therefore, with regard to the future of the secretarial professional, five interviewees believe that the scope of work may have some changes due to the full intermediary of technological and digital tools. As an example of activities that they stopped doing with the home office, telephone service, reception of guests and executives from other headquarters, maintenance of office materials and infrastructure, and organization of travel and events were mentioned. On the other hand, other activities were enhanced, such as the writing of minutes, cited by E1, since the number of videoconferences increased significantly, and, consequently, greater requisition and scheduling of meetings.

Concerning the skills, the interviewees mentioned that most of those that were required before the remote modality, continue to be demanded. However, due to the autonomy and freedom provided by the home office regime, some skills were more valued by some companies than others. A large part stated that changes were noticed, mainly in the behavioral question, as well as a quick enhancement of technical skills, which were already part of the secretarial profile, but which have now become indispensable.

According to E3, E5 and E8, professionals who will follow this area will need to develop strongly in Information and Communication Technologies, and know a lot about administration and strategy, in order to be useful and assertive in supporting decision-making. In addition, E1 and E2 stated that communication skills and everything that involves it, such as language and speech, will be one of the most valued, since with remote relationships, there is a greater facility with which information is lost. Finally, E4, E6 and E7 said that everything that is mechanical and repetitive is being replaced by applications and digital platforms, and this means that the secretarial professional needs to focus more and more on behavioral skills, such as creativity, communication, and interpersonal relationship.

Thus, it is noted that the statement by Martins et al. (2018) is validated: the executive secretary who aims to stand out in organizations must seek to meet the demands of the market, with knowledge about Information and Communication Technologies being paramount. Like Andrade et al. (2015), who reiterates that the manipulation of information through the tools of 
Information and Communication Technology becomes essential for the executive secretary to efficiently assist the information management process.

Finally, Cegan et al. (2015) also state that professionals who aim to stand out in the market should be able to act in the strategic areas of organizations, performing tasks and activities that require a more reflective posture and holding broad knowledge about the company where they work.

\section{Conclusion}

The main aim of this study was to raise the perception of executive secretarial professionals about the skills used in remote work. Thus, with the collection and analysis of data obtained through semi-structured interviews, it was possible to discover new skills that this professional demands, as well as skills that have become even more valued in the secretarial area. It is extremely important for future executive secretarial professionals to understand the perceptions of professionals working in this area at a time when the remote and home office work has become a reality due to the pandemic moment. By obtaining information that discuss the possible demands related to the skills required in this new work pattern, they will have the possibility to adapt to this new reality, investing in training, which will provide them with opportunities to enter the current job market. This is because, according to theoretical studies presented in this research, the hybrid model or even the home office will be the new configuration of organizations, as they demonstrate positive aspects in several ways, both for the employer and the employee.

When conducting research in this sense, eight executive secretarial professionals currently working in private organizations were interviewed. Based on their responses, it was found that only one respondent had already experienced work in the remote mode, and, therefore, there was no change in activities and assignments. The rest of the sample had its scope of work partially changed, and only one interviewee had to change areas due to lack of demands in the position of executive secretary.

Among the main results concerning technical skills, it was found that much of the information flow has become digital. In this perspective, as the executive secretarial professional facilitates this flow, it was required to have an exponential mastery of writing cohesive and coherent texts, in order to minimize, to the maximum, the communicational noise. In addition, it was observed that skills like mastery of video conferencing platforms, online agenda, software management, among others, were mentioned by all respondents as those that demanded the most study and adaptation, also becoming essential for the remote modality. 
In the case of behavioral skills, self-management stands out, specifically in the matter of routine and self-knowledge, since the freedom and autonomy provided by the home office lead the opportunity for each one to divide their time as they wish, without any supervision. As a result, this professional will need to understand how his own productivity works, to make the best choices when planning his routine. In addition, curiosity was mentioned as being largely responsible for a faster adaptation to this new modality, since it is established as a skill of openness and willingness, to learn new tools and forms of conflict resolution as well as new processes.

Regarding the interviewees' perception of the future of the secretarial professional, it was noted that the majority stated that the scope of work will be transformed. Because they believe that companies see remote work as an opportunity to reduce their costs and improve the quality of life of their employees, they suppose that remote work may constitute the new standard modality.

The impacts of the pandemic on the different types of managerial work are not yet entirely possible to be analyzed or measured. However, we believe that observing the workers' practice and perception regarding reality is important. From this paper, we can mention that the pandemic consolidated the institution of remote work, which in the short time will be naturally acceptable for several organizations to consider remote work as productive and valuable. In the secretariat, we can say that the behavioral skills and competences are accentuated, because the professionals are able to show their skills in a more forceful way, proving to be essential for negotiations in business where technology unfamiliarity will not be tolerated.

In the effort to complete this article, we understand that some answers cannot be found yet, despite of the magnitude of this pandemic and his impacts. This work becomes important to register a unique moment, so that we can make analyzes, balance sheets and plans to avoid mistakes in the future and take advantage of all the potential of professionals in business, especially secretarial workers. We can learn, that remote work has brought new perspectives and will probably still be widely practiced in the coming years by organizations, bringing development and changes to all employees.

The limitation of this research is the fact that it is impossible to generalize the results, since the study only contained a small sample of respondents, and also for the wideness of the theme. The area will benefit from a study with a larger sample, as well as a more varied one, with research subjects from the five regions of Brazil. In this way, it would be possible to compare the data in more detail and with greater development of results and inferences.

Finally, it is suggested that further research should be carried out with a specific focus on skills such as curiosity and self-knowledge in remote secretarial routine, In addition, it would 
be interesting to conduct a study with the employers of these professionals, to understand the point of view of those seeking certain skills when hiring someone remotely. Further research could also analyse the changes and needs in the context of both private and public sectors.

\section{References}

Ahrendt, D. et al. (2020). Living, working and COVID-19: First findings - April. Eurofound.

Aguilar, L. D.; \& Souza, R. B. (2019). Uma breve análise do potencial da formação continuada como instrumento para o desenvolvimento das competências e habilidades requeridas pelo mercado de trabalho. Revista de Gestão e Secretariado (GeSec), São Paulo, v.10, n.1, p. $1-25$.

Almeida, W. G. de; Borini, F. M.; Souza, E. C. P. (2018). Competências comportamentais dos profissionais de secretariado: o impacto da atuação internacional da empresa. Revista de Gestão e Secretariado (GeSec), São Paulo, v. 9, n. 1, p 1-17, jan. /abr.

Andrade, T. et. al. (2015). Ferramentas de tecnologia da informação e comunicação como suporte às atividades do secretário executivo. Revista de Gestão e Secretariado (GeSec). São Paulo, v. 6, n. 2, p 65-87, maio /agosto.

Barbosa, V. et. al. (2020). O futuro do trabalho depois da COVID-19. Mostra de Inovação e Tecnologia, Centro Universitário São Lucas, Rondônia. Recuperado em 28 de setembro de 2020 de: <http://inotec.saolucas.edu.br/index.php/mit/article/download/237/282>

Bardin, L. (2006). Análise de Conteúdo. Lisboa: Edições 70.

Bernardo K. A. S. et al. (2020). O trabalho remoto/home-office no contexto da pandemia COVID-19. Recuperado em outubro de 2020 de: $<$ https://www.eco.unicamp.br/remir/index.php/condicoes-de trabalho/190-o-trabalhoremoto-home-office-no-contexto-da-pandemia-covid-19>.

Brandão, H. (2005). O que é gestão por competências? Brasília: Ed. Enap.

Brandão, H. (2007). Competências no trabalho: Uma análise da produção científica brasileira. Estudos de Psicologia. n. 12, pp. 149-158.

Bouquet, C. (2020). How COVID-19 caused the future of work to arrive early. Recuperado em 15 de outubro de 2020 de: <https://www.imd.org/research-knowledge/articles/HowCOVID-19-caused-the future-of-work-to-arrive-early/>

Cegan, E.; Muller, R.; Oliveira, V. S. de. (2015). Perfil do Profissional de Secretariado Executivo na Gestão Contemporânea: Evidências a partir dos ingressantes no mercado de 
trabalho da cidade de Curitiba, e das demandas empresariais. - Revista de Gestão e Secretariado (GeSec), São Paulo, v. 6, n. 3, p 129-151, Set/Dez.

Coeckelbergh, M. (2020). The Postdigital in Pandemic Times: a Comment on the Covid-19 Crisis and its Political Epistemologies Springer - Postdigital Science and Education. University of Vienna, Vienna, Austria.

Cordeiro, L. P.; \& Rosa, A. B. G. da. (2018). Inteligência Emocional no trabalho. Recuperado em 6 de agosto de 2020 de: < http://www.scielo.br/pdf/paideia/v16n35/v16n35a05.>

Costa, A. M. et al. (2020). Metodologia para o desenvolvimento de competências secretariais no contexto da gestão universitária. Revista de Gestão e Secretariado (GeSec), São Paulo, SP, v. 11, n. 1, jan. / abr., p. 151-175.

Dalmau, M. B. L; \& Leal, F. G. (2014). Análise das competências secretariais requeridas pela Universidade Federal de Santa Catarina em comparação ao perfil profissiográfico do secretário executivo. Revista de Gestão e Secretariado - Revista de Gestão e Secretariado (GeSec), São Paulo, v. 5, n. 3, p 143-174, set./dez.

Durante, D. (2012). Pesquisa em Secretariado: Cenário, perspectivas e desafios. Santa Maria: UPF Editora.

Durante, D. Forms of Incompetence. In: Sanchez, R. \& Heene, A. Theory Development for Competent-Based Management. Greenwich, CT: JAI Press, 2002.

Durante, D.; \& Fávero, A. (2009). Gestão secretarial: formação e atuação profissional. Santa Maria: UPF Editora.

Dutra, J. (2002). Gestão de pessoas: modelos, processos, tendências e perspectivas. São Paulo: Atlas.

Dutra, J. (2004). Competências: Conceitos e instrumentos para a gestão de pessoas na empresa moderna. São Paulo: Atlas.

Fleury, M. (2002). A gestão de competência e a estratégia organizacional. In: Fleury, M. As pessoas na organização. São Paulo: Editora Gente.

Fleury, M. (2004) Alinhando estratégia e competências. Revista de Administração de Empresas. vol. 44. n. 1. pp. 44-57. jan-mar.

Fontes, J. H. O. (2018). Inteligência Emocional e o Desenvolvimento das Competências do Profissional de Secretariado Executivo. Trabalho de Conclusão de Curso, Graduação em Secretariado Executivo, Universidade Federal de Sergipe, São Cristóvão.

Gil, A. C. (2010). Como Elaborar Projetos de Pesquisa. 5. ed.São Paulo: Atlas.

Godoi I, A. (2006). Pesquisa qualitativa em estudos organizacionais: paradigmas, estratégias e métodos. São Paulo: Saraiva, pp. 115-146.

Revista Gestão e Secretariado (GeSec), São Paulo, SP, v. 12, n. 3, set./dez., 2021, p. 111-135. 
Hayter, S. (2020). Efeitos da pandemia no mercado de trabalho. Recuperado em 21 de agosto de 2020 de: <https://brasil.un.org/>

Lana, R. M. et al. (2020). Emergência do novo coronavírus (SARS-CoV-2) e o papel de uma vigilância nacional em saúde oportuna e efetiva. Cad. Saúde Pública.

Maia, F. L..; Muller, R. (2020). Relatório Técnico de Pesquisa: trabalho remoto no secretariado no cenário da pandemia COVID-19. 26 p. Curitiba: GEPSEC.

Martins, C. B.; Moreira, K. D.; Souza, T. de. (2018). Teletrabalho: Um Segmento de Atuação para o Profissional de Secretariado. Revista Perspectivas Contemporâneas, v. 13, n. 1, p. 1- 17, jan./abr.

Ministério da Saúde. Brasil confirma primeiro caso da doença. Recuperado em 8 de junho de 2020 de: https://www.saude.gov.br/noticias/agencia-saude/46435-brasil-confirmaprimeiro caso-de-novo-coronavirus $>$.

Moreira, K. D. et al. (2016). As competências contemporâneas do secretário executivo e a relação com as competências do middle manager. Revista de Gestão e Secretariado (GeSec), São Paulo, v. 7, n. 1, p. 45-66, jan./abr.

Oliveira, T. D. de, \& Tosta, L. V. (2020). O “novo normal” e a qualidade de vida do trabalhador: uma análise das mudanças em decorrência da COVID-19. Revista GETS, Sete Lagoas, v. 3 (Edição Especial): p.3 - 19.

ONU- Organizações da Nações Unidas. Como a COVID-19 pode mudar o futuro do trabalho. Recuperado em 15 de julho de 2020 de: <https://nacoesunidas.org/como-a-covid-19-podemudar-o-futuro-do trabalho/>

Santos, P. M. \& Ferreira J. L. (2014). Eficiência e inovação: a adaptabilidade do profissional de secretariado às exigências do mundo contemporâneo. Repositório Instituto Técnico de Viseu, Lamego, p. 70-75.

Saunders M.; Lewis, P.; Thornhill, A. (2009). Research methods for business students Harlow / England: Pearson Education Limited.

Silva, A. A. M. da. (2020). Sobre a possibilidade de interrupção da epidemia pelo coronavírus (COVID-19) com base nas melhores evidências científicas disponíveis. Rev. Bras. Epidemiol 2020. Recuperado em 12 de julho de 2020 de: $<$ https://www.scielo.br/scielo.php?pid=S1415790X2020000100100\&script $=$ sci_arttext $>$.

Toffler, A. (1980). A Terceira Onda. Rio de Janeiro, Record.

Werner, A.; Oliveira, V. S. de. (2014). Secretariado Executivo e Relações Públicas: uma parceria de sucesso. Curitiba: Intersaberes.

Revista Gestão e Secretariado (GeSec), São Paulo, SP, v. 12, n. 3, set./dez., 2021, p. 111-135. 
Zanella, L. (2009). Metodologia da pesquisa. Florianópolis: SEAD / UFSC.

Submetido em: 29.03.2021

Aceito em: $\quad 31.05 .2021$ 